\title{
Research Practices in Critical Discourse Analysis: Constraints and Challenges
}

\begin{abstract}
The paper is an in-depth analysis of the constraints and challenges that the researcher of Critical Discourse Analysis (CDA) faces in practices connected to the research processes. To fully understand where that trouble derives from, we need to examine the notion of discourse and the process of CDA itself. Then the major issues will be exemplified by particular experiences gained in the process of conducting the research project "Women in Intimate Relationships: The Empirical and Critical Study” financed by the Polish National Science Centre (NCN no 2011/01/D/HS6/02470). On one side, the text is an attempt to structure and systematize the knowledge about difficulties caused by the CDA processes, but on the other, it can be read as a kind of "warning notice" that can save very young researchers from making significant mistakes before they start their CDA investigations.
\end{abstract}

\section{Keywords:}

Critical Discourse Analysis, research practices, project design, common difficulties, researcher's constraints

\section{INTRODUCTION}

The author's need to explore research practices within Critical Discourse Analysis (CDA) appeared just after finishing the project "Women in Intimate Relationships: The Empirical and Critical Study” financed by the Polish National Science Centre (NCN no 2011/01/D/HS6/02470). Such insight was supposed to be the catharsis

1 Faculty of Social Sciences, University of Warmia and Mazury in Olsztyn, Poland. E-MAIL: monika.grochalska@uwm.edu.pl ORCID: https://orcid.org/0000-0003-2942-3309 
achieved through verbalization of the doubts and perceived mistakes as well as the attempt to systematize major possible difficulties in order to avoid them in future projects. From the perspective of early-stage CDA analyst, the analysis process seems extremely complex and puzzling. Thus, starting from the very beginning can ease and organize the whole reasoning about the causes of obstacles and limits of CDA.

\section{DISCOURSE AND DISCOURSE ANALYSIS}

Firstly, it is necessary to bear in mind that there is no one explicit and clear definition of the discourse. Clearly, it results in many different approaches to discourse analysis. Michel Foucault cited 23 meanings of discourse during a lecture at College de France, which does not make it easier to understand and synthesize this concept. In general, there are two major ways of understanding the discourse. Firstly, as a power tool, and secondly, as a cultural fact. According to Teun van Dijk (2001, p. 12), discourse is a text in the context or a communication event. As an ambiguous concept, its specification requires the use of additional terms, such as "medical discourse", "political discourse", or "scientific discourse". Helena Ostrowicka (2014, pp. 59-60) in the context of educational analyses distinguished: scientific discourses (produced by scientists), public discourses (produced by politicians, journalists), and practical discourses (produced by practitioners directly involved in a particular social field). In Foucault's view, the discourse refers to "ways of constituting knowledge, together with the social practices, forms of subjectivity and power relations which inhere in such knowledges and relations between them. Discourses are more than ways of thinking and producing meaning. They constitute the 'nature' of the body, unconscious and conscious mind and emotional life of the subjects they seek to govern” (Weedon, 1987, p. 108). Interpreting the theory of Ernesto Laclau and Chantal Mouffe, the discourse can be defined as all forms of social reality emerged against the background of discursive fields, fields of discourse and discourses, which can be defined as differential relation systems for the production of meanings (Gąsior-Niemiec, 2008, p. 296). In these systems, semantic aspects of language and pragmatic aspects of action coexist. In Laclau's words, the discourse is a sensible whole that goes beyond the distinction between linguistic and non-linguistic phenomena (Laclau, 2002, p. 560).

Moreover, three major spheres of discourse can be distinguished (Gąsior-Niemiec, 2008): text, discourse practice, and social practice. In discourse analysis, it results in the constitution of three levels of analysis: 
- $\quad$ study of vocabulary, grammar, structure and coherence of the text(s),

- the process of production, distribution and consumption of the text (who, for whom, for what purpose did it?), the way of constructing and perceiving the text,

- emphasizing the political, economic, cultural and ideological function of the text(s).

Without this kind of knowledge, it is hard to understand the attempts and struggles of CDA practitioners. In their perspective, the nature of the whole social reality is discursive. The essence of the social world is arbitrary, conflictual and wobbly (Gąsior-Niemiec, 2008, p. 291). At the same time, the constructivist research perspective implying the perception of social facts as the meanings created by the subject makes it possible to interpret everything social in terms of discourse.

\section{THE SPECIFICITY OF CRITICAL DISCOURSE ANALYSIS}

Overall discourse analysis is interpretive and explanatory. The analysis process is framed by exposing discursive structures that determine mental processes and enable the creation of social representations. There are three main types of discourse analysis highlighted by the theorists and researchers (Grzymała-Kazłowska, 2004): linguistic analysis, sociological analysis, and critical analysis. Whereas linguistic analysis is focused mainly on a written text and structural description of the discourse, the sociological analysis makes investigations of statements and texts in the context of the major task. Sociological analysis is processual, descriptive and explanatory. Likewise, it serves cognitive goals. Nonetheless, the critical analysis extends the field of interests by adding to previously mentioned features also normative aims, socially engaged practices and making the change in a social world.

CDA is not a specific research direction and there is no one cohesive theoretical framework. The uniqueness of CDA lies in a fact that it functions as "a bridge" between micro- and macro-level approaches. Micro-level is connected to the particular language uses, the discourse structures and communication. But the macro-level of analysis refers to power, domination and inequality. Significantly, in the view of many discourse theorists, power manifests itself not only in acts of oppression by dominant groups but in the "obviousness" of everyday life (Foucault, 1988b). In consequence, two major CDA questions emerge. First of them is: "How do dominant groups control discourse?", and the second: "How does such discourse control the minds and actions of people (and especially 
less-privileged groups), and what are the consequences of this state?”. Because of specific goals of CDA, the significant subject of analysis for CDA practitioners are the ways of controlling the minds and actions of less-privileged groups in society. However, the discourse controls not only the less-privileged, but also the broader part of society, especially through processes of naturalization. Discourse is a tool for shaping minds of not only the oppressed, but also shaping minds of the shapers. In terms of Foucault, it is possible, because the power is "dispersed". He refers not to the Power "with a capital $\mathrm{P}$, dominating and imposing its rationality upon the totality of the social body" (Foucault, 1988a, p. 38). There are rather multiple power relations taking on different forms, penetrating all spheres - family relations, institutions, administration (Foucault, 1988a). These questions organize CDA around the topics connected to the perception of inequalities dependant on the position in the social structure. Certainly, we can say that CDA is not a "direction", "school” or "specialization" within discourse analysis, but rather a perspective, an approach or an attitude that may appear in conversation analysis as well as in sociolinguistics or ethnography. This type of analysis is determined more by the dispositions of the researcher than by the chosen methods or procedures.

Based on the work of researchers located in this perspective, one can distinguish various approaches developed by individual researchers, i.e. (Krzyżanowska, 2013):

- $\quad$ the Viennese school, developing the discourse-historical approach (DHA), represented by Ruth Wodak, Martin Reisigl, Michał Krzyżanowski,

- Teun van Dijk's socio-cognitive approach,

- British systemic-functional school developed on the works of Norman Fairclough,

- $\quad$ psychologically oriented group from Loughborough University represented by Michael Billig,

- socio-semiotic approach, developed by Teun van Leeuwen,

- $\quad$ a Duisburg school represented by Siegfried Jäger.

All facts cited suggest that within CDA it is possible to use various theories, descriptions, and methods depending on the socio-political aims (Jabłońska, 2006), bearing in mind that language is the "architect of all socialization processes" (Jabłońska, 2006). As such, it is demonic in its nature, because it hides the violent relations of power, creates them and contributes to their consolidation (Bourdieu, 1991; Foucault, 1988b). But at the same time, CDA does not reduce the social sphere only to language (Laclau \& Mouffe, 1985). CDA examines the relations between what is 
discursive (sphere of meanings) and what is non-discursive (sphere of materiality). These both are so mixed up and intertwined that it is impossible to separate them in a social world. Discourse is constitutive and constituted at the same time (Fairclough, 1995). In Teun van Dijk’s socio-cognitive approach, CDA is an analytical study of discourse, unmasking power relations, revealing dominance and subordination of certain groups, and inequalities that are reproduced and perpetuated by the text in a social and political context. The researcher's task is to understand and expose these relations as well as to stand against inequalities (van Dijk, 2009b).

\section{TECHNICAL ASPECTS OF CRITICAL DISCOURSE ANALYSIS}

In CDA seen as a research approach (Wodak \& Meyer, 2009), we can easily distinguish a few steps leading to reaching the research objectives. First is the selection of phenomenon to be observed, for example, racism or sexism. In the second step, one should explain the theoretical assumptions underlying the study. Then, using different methods, the researcher should attempt to combine theory with observations. Here, it is possible to apply three levels of analysis:

- linguistic analysis - first only the surface of the text, then analysis of pronouns, attributes, modes and tenses. According to van Dijk (2001), the complete analysis of discourse in CDA is impossible, so we are supposed to choose those aspects that reflect best the power relations (intonation, accents, consistency, choice of the topic, moments of hesitation, correcting statements, etc.);

- socio-cognitive analysis - here social representations are being taken into consideration. Social representations are understood as "collective frames of perceptions performing translation between external requirements and subjective experience” (Wodak \& Meyer, 2009, p. 25) and a framework organising the acquisition of specific knowledge, which allows understanding the "coded language";

- analysis of intertextuality, interdiscursivity and context - at this stage we investigate how the text is connected to other texts, other discourses existing in the public sphere and how it is positioned in the context (we can achieve it mainly through de-contextualisation).

It is important to acknowledge that data collection and analysis are not separated in time, they occur simultaneously (similarly to grounded theory methodology). Sampling - a selection of texts included in the corpus of data - is fully intentional. 
There are numerous concepts and ideas of how the analysis can be lead. Van Dijk (2001) points out six levels of analysis:

1. Analysis of semantic macrostructures (topics);

2. Analysis of local meanings, e.g., presuppositions, allusions, doubts;

3. Analysis of "subtle" formal structures;

4. Analysis of global and local forms of discourses;

5. Analysis of specific language implementations (e.g., hyperbola);

6. Context analysis.

Reisigl and Wodak (2001) write about only four phases:

1. Determining the content/topics of the discourse;

2. Discursive strategies (e.g., argumentation);

3. Linguistic measures;

4. Specific, context-dependent linguistic implementations (as symbols).

R. Scollon (2001) advocates the use of five-stage analysis:

1. Actions;

2. Practice;

3. Mediation measures;

4. Practice links;

5. Practice communities (and the identities they produce).

Whereas Fairclough (1995) applies four major steps in his version of CDA:

1. Focus on a specific social problem;

2. Identification of dominant styles, genres, discourses;

3. Considering the scope of diversity within styles, genres, discourses;

4. Identification of areas of resistance to colonization processes by dominant discourses.

Then he suggests working on structural analysis of the context, interactive analysis of linguistic aspects and analysis of interdiscursivity.

Those concepts differ, but they all may lead to valuable results and demystifying power relations hidden within social structures. However, being the beginner in the CDA field, it is extremely hard to choose the one specific approach. 


\section{THE CASE OF THE RESEARCH PROJECT ON WOMEN'S INTIMACY}

The specification of constraints and challenges will be presented on the basis of experiences derived from the project "Women in Intimate Relationships: The Empirical and Critical Study" financed by the Polish National Science Centre (NCN no 2011/01/D/HS6/02470). In the presented project, the qualitative research perspective was used. Data was collected through focus groups interviews and individual in-depth interviews. Moreover, chosen public discourse messages were analysed. The research sample consisted of women over 18 years old living in permanent relationships - formal and informal, homo- and heterosexual for at least two years. All collected data were analysed with the use of Critical Discourse Analysis as a global analytical frame. However, it is necessary to add that in the research an unusual methodology was created, taken into consideration the topic studied. In this case, discourse is one of the elements of the social practices and every social practice involves such elements as productive activity, means of production, social relations, social identities, cultural values, consciousness, and semiosis (Fairclough, 2001). Innovative research approaches that allow joining discourse analysis with other methodologies make also possible to keep in sight both the role of discourse in the moments of practices and the dialectical relations between them (Ottoni, 2018). Thus, the methodological concept was inspired by van Dijk's socio-cognitive approach to CDA, but there were two major methodological choices that are rarely used in CDA:

- $\quad$ the use of interviews (IDI and FGI) as the source of research material (where in CDA mostly media texts are being analysed),

- $\quad$ the use of social representations as the main analytical category (in CDA the dominant category become usually discursive strategies).

Then, only the goal of analysis locates it in critical discourse studies, but methodological procedures are eclectic and derived from the specificity of the research questions.

It is in line with van Dijk's perspective who stresses the role of cognition in mediation between discourse structures and social structures. One of aims was to show how real language users produce and understand discourse, how their personal and socially shared beliefs affect discourse production and how these are in turn affected by discourse (van Dijk, 2009a, p. 79). The project followed van Dijk's concept of social cognition understood as the beliefs or social representations that people share with others of their groups or community (van Dijk, 2009a, p. 78). 
In the aforementioned project, those shared social representations of intimacy and relationships which include knowledge, attitudes, ideologies, values and norms were being analysed. At the same time, language is treated as an important part of social reality and it is harnessed to the processes of reproducing inequality. It is not uncommon for language to have an active role in reproducing inequalities, but inequalities themselves have a different reality than just linguistic, and language is used to naturalize them. The researcher's task is to bring to light the traps hidden in the language that communication participants are not aware of (Bielecka-Prus \& Horolets, 2013). Also other researchers recognize the possibility of conducting research on discourse within the framework of the Theory of Social Representations in broader perspective of Critical Discourse Analysis (Zbróg, 2017).

In CDA researchers often try to multiply the techniques of collecting and analyzing data that become the basis for formulated conclusions (Wodak, 2001, p. 65). This is also the case in the analysed project. Selection of research methods was premised on the discourse theory. The discourse in the aforesaid project was defined as a relatively persistent map of meanings or ways of speaking that make objects or practices significant. The arrangement of the sphere of meanings reconstructed in the project is a consequence of the influence that power exerts on the area of social practice. The objective of research was reconstruction of women's experiences related to functioning in intimate relationships through the prism of the practical discourses they produce (Ostrowicka, 2014, p. 60), as well as reconstruction of discourses about intimate relationships that coexist in public sphere and an attempt to determine the area of mutual interpenetration of discourse with everyday experience using achievements of the theory of social learning, in particular, based on the phenomenon of social cognition and S. Moscovici's theory of social representations. The final result was the proposal of interpretative frameworks of the phenomenon of intimacy in a relationship different from existing ones (cf. Kopciewicz, 2011, pp. 112-113).

The main research question was formulated as How do nowadays women experience "being in intimate relationships" and what is the role and significance of cultural premises and expectations towards women for these experiences? As mentioned above, besides using the secondary data (Rubacha, 2008) such as popular handbooks and TV series, there were two additional data sources:

- FGI - focus groups interviews (or an interview with the thematic group according to K. Rubacha), in particular, the affinity groups (groups with similar interests; Gawlik, 2012), 
- $\quad$ IDI - semi-structured individual interviews, in the form of an episodic interview, which is recommended by U. Flick (2006) to examine social representations.

The analysis was computer-assisted by using Open Code 4.02 - the tool designed for analyzing qualitative data under a freeware license. In the collected material such elements as: i) social representations of intimacy, relationships and femininity, ii) strategies of being in a relationship, iii) strategies of dealing with the oppression, iv) topos of discourse, v) rituals (practices) in relationships, were analysed.

\section{MAJOR CONSTRAINTS AND CHALLENGES OF THE CDA ANALYSIS}

The most important and at the same time the most frustrating for the young researchers is the fact that the variety of options available through the numerous traditions of discourse analysis can make issues of methodology problematic. As long as each tradition has its epistemological position, concepts, procedures, and a particular understanding of discourse and discourse analysis, it is difficult to choose and use the exact approach to the chosen research topic. Innovative research strategies developed for the needs of a particular project very often face criticism from the researchers embedded in more traditional approaches. The less experienced researchers have to choose between sticking to the less flexible but safe traditional modes and creating their eclectic methodology but expose themselves to the criticism. Similarities and differences between concepts may cause confusion. When the confusion spreads, an explanation of concepts and justification for their use seems to be the proper way of dealing with this. In the above-mentioned project, an innovative approach was developed, but each step of the analysis was carefully explained and rationalized. The general lack of explicit techniques for researchers to follow has been indicated as a hindrance (Morgan, 2010).

The other issue in the CDA mixed studies is the fact that meaning is never fixed and everything is always open to interpretation and negotiation. Such a way of thinking may disrupt longstanding notions of gender, autonomy, identity, choice. Such disruption can be very disturbing, but at the same time is interesting and challenging. Each tradition within discourse analysis has been once critiqued. For example, conversation analysis is said to be narrow, but Foucauldian discourse analysis is said to be too broad (Mogashoa, 2014).

Most of the CDA critics agree that texts are arbitrarily selected and limited in length, which leads to concerns over the representativeness of the texts selected. 
There are also very serious limitations and difficulties in drawing any conclusion. In the above-mentioned project, this issue was partly eliminated by choosing some of the texts based on the results of interviews with women. Basically, they indicated the texts being their most common source of knowledge about intimate relationships. The study aiming for credibility should be being as truthful and transparent as possible in giving sufficient details about the data source. The data should be obtained systematically and great emphasis should be put on the description of the methodology to clearly explain how the data has been collected to make the analysis transparent so that the reader can trace and understand in-depth textual analysis (Wodak \& Meyer, 2009, p. 11). Moreover, the issue of making much interpretation out of little evidence can be resolved by carefully addressing potential criticisms (Sriwimon \& Zilli, 2017).

To address the criticism of prioritizing context over text, a CDA study should start from textual analysis. Only then the results can be interpreted and discussed against the sociopolitical context. To do it properly, the texts' production and consumption should be discussed. In the presented project, the influence of ideologies found in the textual analysis on everyday practices was shown (Sriwimon \& Zilli, 2017). Since CDA is a problem-oriented research approach, that is mainly motivated by a social or political problem rather than a linguistic issue (Wodak, 2001). In this case, it is necessary to adopt an eclectic approach to improve the analysis incorporating the knowledge about the historical, political, and social contexts of the problem under investigation and to explain how social phenomena are interconnected, and how power structures and ideologies are hidden behind discourse (van Dijk, 2001).

CDA is interpretive and subjective. The CDA analysts may have their subjective influence on the analysis and usually cannot separate their own values and beliefs from the research they are doing. The only way of dealing with this is using their preconceptions and personal beliefs as an advantage shaping and giving meaning to the production of discourse basing on them and openly confess on them (Wodak, 2009).

According to Nguyen (2014), CDA should also include interviews with producers and consumers of discourse and not just base on the analyst's view. The critical discourse analysts should be aware of their position because CDA can neither prove the author's intentions, nor the audience's interpretation. The presented project aims also at examining the role of the audience (women living in relationships) in the consumption and interpretation of discourse, not just simply relying on the analyst's interpretation of the texts. 
However, the analysed project is not a typical CDA study because there are additional sources of data taken into consideration, so the researcher faced also some challenges which are connected to qualitative research in general. The researcher's constraints and challenges in this matter were connected to three main dichotomies:

- theory versus practice,

- opportunities versus requirements,

- project management versus life issues.

In the first area, the main concern of the researcher conducting CDA for the first time is that discourse analysis is something disparate from Critical Discourse Analysis. CDA is much more complex and extensive. The multiplicity of methodological concepts causes confusion and the difficulty of choosing the right procedure. There occurs also the need to adapt chosen procedures to the undertaken social problem. All this requires a lot of research awareness.

The innovative and untypical methodology demanded using also the bricolage technique in combining different methods of collecting data and analysing them. The use of this technique also causes a lot of trouble. Bricolage as creating the representations system of many different pieces that match a specific, complex situation, gives the researcher a lot of freedom and flexibility, but on the other hand, it is very demanding. The bricolage itself changes, takes on new forms, and the bricoleur adds new tools, methods, techniques of representation and interpretation (Denzin \& Lincoln, 2009, p. 24). By adopting such a role in research, new tools and techniques can be even invented or combined, without having to decide in advance which interpretive practice will be used. These types of issues emerge during the analyses which is both releasing and paralyzing. The theory is compelling, but in practice, conducting such unstructured analysis can be tough.

The second mentioned area, opportunities versus requirements, is mainly connected to a lack of experience and competence of the early-stage researcher. In the case of the social science researcher, especially linguistic skills are often the weakness. For the researcher who is unexperienced in CDA, it is a totally novel approach. Without the right attitude oriented to constant learning, valuable analysis is impossible. Another challenge is dealing with a lot of information/data. For very young researchers it can be quite frightening. Surely, there are some tools which can be efficient support in the process of analysis, but using professional software can be also difficult. Definitely, again the researcher should be prepared for learning. Another obstacle is choosing the right technique of transcriptions. 
In the considered project Jefferson's technique was used, but it turned out to be hard to implement and also to read. There occurred severe difficulties with translating those transcripts into English, which is necessary when one wants to publish the research results in international high-impact journals. Due to the purposes of translation into English, transcription was simplified (transcription marks were omitted). Only very well skilled researchers are able to construct less extensive texts deriving from the whole analysis, which remain fully understandable and clear to the readers.

Last but not least is the role of the "human factor". Focus group interviews organization was very demanding. There were a lot of difficulties in constructing the appropriate groups. Even when the groups were complete, the participants did not attend the meetings. One of the ways of dealing with such issues is finding and including into groups more people than is really needed. Another method to overcome these constraints is allocating the remuneration for participants. But we have to keep in mind that not every project is fully financed by the external entities. Writing the grant proposal with the usage of FGI technique, the remuneration as the part of the planned budget is certainly worth taking into account. Also, the role of a moderator/facilitator in the group is not easy. To manage this task and collect the information needed, it is necessary to have certain communication skills. The audio and video recordings are impossible to eradicate and the same time quite safe from the researcher's perspective. Despite that, the interviewees often see this as a threat. Sometimes it is difficult to get informed consent. Moreover, technical aspects and tools can be unreliable. The researcher should be prepared for even the most unexpected situations. Individual in-depth interviews also become troublesome in practice. The selection of appropriate "cases" according to the sample construction, then obtaining their informed consent, as well as ensuring appropriate conditions and environment (a good place to talk) is a very demanding process. During the interview, it is crucial to overcome the resistance and fully understand the language and concepts used by every respondent. Again communication skills become crucial.

In the third dichotomic distinction, the major problem is to reconcile the project management process, living conditions and unpredictable events. Unpredictability is inevitable in the qualitative research process. During the research process, in fact, the time becomes your worst enemy, because CDA is really challenging and time-consuming. Usually, it takes more time than you assume at the beginning. Bearing in mind that typically reconstruction of initial concepts, the research approach and adaptation of methods to the specificity of the study are unavoidable, better allocate more time and resources than you think in the beginning. The antidote can be good and systematically repeated planning throughout the whole research process and a large experience of the researcher in qualitative 
research. The challenge is also to deal with a lot of information/data, which in technical terms is meant to be facilitated by the use of the CAQDAS (Computer-Assisted Qualitative Data Analysis Software) which is a group of programmes such as NVivo, Weft QDA, or OpenCode. Learning to handle a variety of software features nowadays can be done online, through tutorials available on the YouTube platform. But also CAQDAS applications training can be helpful and ensure the necessary knowledge and skills to manage the analysis process. Difficulties in project implementation may also arise from the conditions of working with people. Acquiring interviewees can be cumbersome. Besides, difficulties are usually related to the process of interviewing. Breaking down resistance, providing appropriate conditions/environments, using an understandable language are communicational challenges. On this issue also the researcher's experience can be a significant advantage.

Concluding, CDA can be highly challenging, especially to inexperienced, early-stage researchers, but overcoming constraints is possible mainly due to taking advantage of reading texts and listening to more experienced analysts. CAQDAS training and interpersonal competence training would also be eligible. With such preparation, CDA and qualitative research, in general, can be an exceptionally satisfying activity.

\section{References}

Bandura, A. (2007). Teoria społecznego uczenia się. Warszawa: Wydawnictwo Naukowe PWN.

Bielecka-Prus, J., \& Horolets, A. (2013). Rekonstrukcja praktyk analizy dyskursu na podstawie wybranych anglojęzycznych czasopism dyskursywnych. Przeglqd Socjologii Jakościowej, 9(1), pp. 152-185. Retrieved from: www.przegladsocjologiijakosciowej.org, [access date: 12.04.2020].

Bourdieu, P. (1991). Language and Symbolic Power. Cambridge: Polity Press.

Bourdieu, P. (2009). Rozum praktyczny. O teorii działania. Kraków: Wydawnictwo UJ.

Butler, J. (1993). Bodies that Matter: On the Discursive Limits of 'Sex'. New York: Routledge.

Charmaz, K. (2009). Teoria ugruntowana. Praktyczny przewodnik po analizie jakościowej. Warszawa: Wydawnictwo Naukowe PWN.

Denzin, N.K, \& Lincoln, Y.S. (2009). Wprowadzenie. Dziedzina i praktyka badańjakościowych. In: N.K. Denzin, \& Y.S. Lincoln (Eds.), Metody badań jakościowych. Vol. 1 (pp. 19-57). Warszawa: Wydawnictwo Naukowe PWN.

Erikson, E.H. (2004). Tożsamość a cykl życia. Poznań: Zysk i S-ka.

Fairclough, N. (1995). Critical Discourse Analysis: The Critical Study of Language. London: Longman.

Fairclough, N. (2001). Critical discourse analysis as a method in social scientific research. In: R. Wodak, \& M. Meyer (Eds.), Methods of Critical Discourse Analysis (pp. 121-138). London: Sage. 
Flick, U. (2006). An Introduction to Qualitative Research. London-Thousand Oaks-New Delhi: Sage Publications.

Foucault, M. (1978). Discipline and Punish: The Birth of the Prison. New York: Pantheon.

Foucault, M. (1988a). Critical Theory/Intellectual Theory: Interview with Gerard Raulet. In: L. Kritzman (Ed.), Michel Foucault: Politics, Philosophy, Culture: Interviews and Other Writings, 1977-1984 (pp. 20-47). London: Routledge.

Foucault, M. (1988b). Technologies of the Self. In: L.H. Martin, H. Gutman, \& P.H. Hutton (Eds.), Technologies of the Self: A Seminar with Michel Foucault (pp. 16-49). Amherst: University of Massachusetts Press.

Foucault, M. (1995). The Birth of the Clinic: An Archeology of Medical Perception. Transl. A.S. Smith. New York: Vintage Books.

Gawlik, K. (2012). Badania fokusowe. In: D. Jemielniak (Ed.), Badania jakościowe. Metody i narzędzia. Vol. 2 (pp. 131-162). Warszawa: Wydawnictwo Naukowe PWN.

Gąsior-Niemiec, A. (2008). Teoria dyskursu Laclau i Mouffe jako narzędzie analizy socjologicznej - przypadek dyskursu „osiedli grodzonych”. In: A. Horolets (Ed.), Analiza dyskursu w socjologii i dla socjologii (pp. 291-316). Toruń: Wydawnictwo Adam Marszałek.

Ghachem, I. (2015). A Sociocognitive Approach to Agency Framing in David Cameron’s 2010 Pre-election Discourse. Critical Approaches to Discourse Analysis across Disciplines, 7(2), pp. 263-282.

Grzymała-Kazłowska, A. (2004). Socjologicznie zorientowana analiza dyskursu na tle współczesnych badań nad dyskursem. Kultura i Społeczeństwo, 48, pp. 13-34.

Hensel, P., \& Glinka, B. (2012). Teoria ugruntowana. In: D. Jemielniak (Ed.), Badania jakościowe. Podejścia i teorie. Vol. 1 (pp. 89-113). Warszawa: Wydawnictwo Naukowe PWN.

Jabłońska, B. (2006). Krytyczna analiza dyskursu: refleksje teoretyczno-metodologiczne. Przeglq̨d Socjologii Jakościowej, 2(1), pp. 53-67.

Jefferson, G. (2004). Glossary of Transcript Symbols with an Introduction. In: G.H. Lerner (Ed.), Conversation Analysis: Studies from the First Generation (pp. 13-31). Amsterdam: John Benjamins Publishing. DOI: 10.1075/pbns.125.02jef.

Kopciewicz, L. (2011). Nauczycielskie poniżanie. Szkolna przemoc wobec dziewczq̨t. Warszawa: Difin.

Krzyżanowska, N. (2013). (Krytyczna) analiza dyskursu a (krytyczna) analiza gender: zarys synergii teoretycznej i metodologicznej. Przegląd Socjologii Jakościowej, 9(1), pp. 62-84. Retrieved from: www.przegladsocjologiijakosciowej.org, [access date: 12.04.2020].

Laclau, E. (2002). Dyskurs. In: R.E. Goodin, \& P. Pettit (Eds.), Przewodnik po współczesnej filozofii politycznej (pp. 555-562). Warszawa: Książka i Wiedza.

Laclau, E., \& Mouffe, C. (1985). Hegemony and Socialist Strategy: Towards a Radical Democratic Politics. London: Verso.

Mogashoa, T. (2014). Understanding Critical Discourse Analysis in Qualitative Research. International Journal of Humanities Social Sciences and Education (IJHSSE), 1(7), pp. 104-113.

Morgan, A. (2010). Discourse Analysis: An Overview for the Neophyte Researcher. Journal of Health and Social Care Improvement, 5(1), pp. 1-7. 
Moscovici, S. (2000). Social Representations: Explorations in Social Psychology. Cambridge: Polity Press.

Nguyen, H.K. (2014). Critique on Critical Discourse Analysis. Unpublished manuscript.

Ostrowicka, H. (2014). Kategoria dyskursu w języku i w badaniach edukacyjnych - w poszukiwaniu osobliwości pedagogicznie zorientowanej analizy dyskursu. Forum Oświatowe, 26(2), pp. 47-68.

Ottoni, M.A.R. (2018). Critical Discourse Analysis and Ethnography [Review of I. Magalhães, A.R. Martins, \& V. de M. Resende, Análise de Discurso Crítica: um método de pesquisa qualitativa. Brasília: Ed. da UnB, 2017. 259 p. Transl. I.A. Lourenço da Silva.]. Alfa: Revista de Linguística (São José do Rio Preto), 62(2), pp. 411-415. DOI: 10.1590/19815794-1807-8.

Reisigl, M., \& Wodak, R. (2001). Discourse and Discrimination: Rhetorics of Racism and Antisemitism. London: Routledge.

Rubacha, K. (2008). Metodologia badań nad edukacją. Warszawa: Wydawnictwa Akademickie i Profesjonalne.

Scollon, R. (2001). Mediated Discourse: The Nexus of Practice. London: Routledge.

Sękowska, M. (2000). Neopsychoanalityczna koncepcja rozwoju psychospołecznego Erika H. Eriksona. In: P. Socha (Ed.), Duchowy rozwój człowieka. Fazy życia, osobowość, wiara, religijność. Stadialne koncepcje rozwoju w ciagu życia (pp. 101-143). Kraków: Wydawnictwo UJ.

Sriwimon, L., \& Zilli, P.J. (2017). Applying Critical Discourse Analysis as a Conceptual Framework for Investigating Gender Stereotypes in Political Media Discourse. Kasetsart Journal of Social Sciences, 38(2), pp. 136-142. DOI: 10.1016/j.kjss.2016.04.004.

Trutkowski, C. (2004). Wybór czy konieczność - o potrzebie wykorzystania analizy dyskursu w socjologii. Kultura i Społeczeństwo, 48(1), pp. 35-50.

van Dijk, T.A. (2001). Critical Discourse Analysis. In: D. Tannen, D. Schiffrin, \& H. Hamilton (Eds.), Handbook of Discourse Analysis (pp. 352-371). Oxford: Blackwell.

van Dijk, T.A. (2009a). Critical Discourse Studies: A Sociocognitive Approach. In: R. Wodak, \& M. Meyer (Eds.), Methods of Critical Discourse Analysis (pp. 62-86). London: Sage.

van Dijk, T.A. (2009b). Society and Discourse: How Context Controls Text and Talk. Cambridge, UK: Cambridge University Press.

Weedon, C. (1987). Feminist Practice and Poststructuralist Theory. Oxford: Basil Blackwell.

Wodak, R. (2001). The discourse-historical approach. In: R. Wodak, \& M. Meyer (Eds.), Methods of Critical Discourse Analysis (pp. 63-94). London: Sage.

Wodak, R. (2009). The Discourse of Politics in Action. London: Palgrave Macmillan.

Wodak, R., \& Meyer, M. (2009). Critical Discourse Analysis: History, Agenda, Theory and Methodology. In: R. Wodak, \& M. Meyer (Eds.), Methods of Critical Discourse Analysis (pp. 1-33). London: Sage. http://www.research.lancs.ac.uk/portal/en/publications/critical-discourse-analysis-history-agenda-theory-and-methodology(d30211d8-a9e4-48cabce6-f5c067d3fffa)/export.html

Wojciszke, B. (2010). Psychologia miłości. Gdańsk: GWP.

Zbróg, Z. (2017). Teoria reprezentacji społecznych w interdyscyplinarnych badaniach nad dyskursem edukacyjnym - potencjał zbiorowego pisania biografii. Kultura-SpołeczeństwoEdukacja, 12(2), pp. 225-243. DOI: 10.14746/kse.2017.12.11. 